\title{
Importance of canopy connectivity for home range and movements of the rainforest arboreal ringtail possum (Hemibelideus lemuroides)
}

\author{
Robyn F. Wilson ${ }^{\mathrm{A}, \mathrm{C}}$, Helene Marsh ${ }^{\mathrm{A}}$ and John Winter ${ }^{\mathrm{B}}$ \\ ATropical Environment Studies and Geography, James Cook University, PO Box 6811, \\ Cairns, Qld 4811, Australia. \\ BPO Box 151, Ravenshoe, Qld 4888, Australia. \\ ${ }^{\mathrm{C}}$ Corresponding author. Email: robyn.wilson@jcu.edu.au
}

\begin{abstract}
Roads and powerline corridors destroy canopy connectivity in the rainforest of north-east Australia. We tested the hypotheses that linear barriers affect (a) the alignment of home ranges, (b) use of habitat either side of linear barriers, and (c) the crossing of them by the strictly arboreal lemuroid ringtail possum (Hemibelideus lemuroides), which is known to be vulnerable to habitat fragmentation. Radio-tracking and a translocation experiment were conducted at a narrow 7-m-wide road and an 80-m-wide powerline. Homes ranges of lemuroid ringtails ranged from 0.15 to 1.67 ha (minimum convex polygon) and were aligned with the road but not powerline corridors. When lemuroid ringtails were experimentally translocated, wider canopy clearings over roads reduced their capacity to return to their original home range, and the powerline corridor was a nearly insurmountable barrier. No possums were observed crossing roads or the powerline corridor at ground level or residing in the intervening matrix, indicating that loss of canopy connectivity has a negative impact on their movements.
\end{abstract}

\section{Introduction}

Forest fragmentation caused by large-scale clearing is recognised as a major threat to fauna at a global scale (Laurance and Bierregaard 1997; Laurance et al. 1998, 2004; Laurance 1999, 2004; Lindenmayer and Franklin 2002; Laurance and Gomez 2005). Forests are also being internally fragmented by infrastructure such as roads, highways, railways, telecommunication and powerlines and this results in a loss of canopy connectivity, an increase in the extent of forest edge and associated edge effects (Goosem 1997). This problem is exacerbated by global climate change, which is predicted to result in less tropical rainforest in the Wet Tropics of Australia (Hilbert et al. 2001) and threaten the survival of fauna species endemic to upland forests within it (Williams et al. 2003).

The highest number of rainforest-dependent vertebrate species in Australia occurs in the upland tropical rainforests of north-east Queensland (Werren 1993). Most are endemic to forests above $700 \mathrm{~m}$, and include the sympatric, nocturnal, leafeating arboreal ringtail possums: the lemuroid (Hemibelideus lemuroides), the green (Pseudochirops archeri), and the Herbert River (Pseudochirulus herbertensis). These animals have restricted distributions and occur in isolated populations (Winter 1984; Werren 1993; Laurance and Laurance 1996). Their habitat has been dramatically reduced and fragmented by clearing since European occupation (Winter et al. 1987; Laurance and Laurance 1996). The remaining contiguous forest is internally fragmented by roads and powerline corridors (Goosem 1997). These may create artifical home-range boundaries and 'territory pile-up' sensu Riley et al. (2006) along them, restricting reproductive opportunities for individuals that manage to cross them. Roads and powerline corridors are known to influence the movements and mortality of terrestrial mammals as they are rarely traversed, even by dispersing individuals (Burnett 1992; Goosem 1997; Riley et al. 2006). Fragmenting populations in this way contributes to a breakdown in metapopulation dynamics and results in a reduction in effective population size (Gilpin and Soulé 1986; Chepko-Sade and Haplin 1987). Small isolated populations may then disappear in an extinction vortex as a result of stochastic events (Laurance 1990; Caughley and Sinclair 1994).

Roads create problems for wildlife that are different from those of powerline corridors (Goosem 1997). Vehicle movements create noise, light, exhaust fumes and dust, and result in wildlife mortality (Goosem 1997; Forman and Alexander 1998). Arboreal mammals are buffered to a degree from the full impact of these intrusions as they live above ground, but roadside maintenance that destroys canopy connectivity may fragment populations of these mammals. When roads fragment populations of arboreal animals they may be forced to the ground to travel between fragments, increasing exposure to human impacts and terrestrial predators. For specialised species, roads result in smaller and possibly less viable populations (Andrews 1990; Bennett 1991; Burnett 1992; Young 1994; Goosem 1997).

In contrast to roads, powerline corridors are invaded by a community of flora and fauna different from that in the rainforest (Middleton 1993; Goosem and Marsh 1997). In north Queensland, the vegetation in the clearing has little structural complexity and is slashed, burned and sprayed with herbicides every 1-2 years. This lack of structural integrity may restrict or 
inhibit the movements of arboreal species and expose them to additional risk of predation by both rainforest and non-rainforest terrestrial predators (see Newman et al. 1988). Complete inhibition of the movements of small terrestrial mammals across a 60 -m-wide powerline corridor filled with tall dense grass, within tropical rainforest, has previously been demonstrated by Goosem and Marsh (1997).

To examine the impact of roads and powerline corridors on the movements and home-range size and shape of arboreal mammals we selected the canopy-dwelling lemuroid ringtail possum as the study species. This species is the most susceptible of the arboreal folivores in the rainforest of far north Queensland to habitat fragmentation (Pahl et al. 1988; Laurance 1990; Laurance and Laurance 1996). It disappears from fragmented and secondary habitats and declines significantly in recently logged forest (Laurance and Laurance 1996; Laurance 1997). Its denning requirements, diet, and degree of arboreality are more specialised than those of other rainforest ringtail possums (Laurance 1990). We investigated the ability of this species to home following translocation across narrow road and wide powerline corridors within contiguous forest, to test the hypothesis that these corridors are barriers to their movements. Forest cover has been shown to influence the ability and pattern of return of forest birds translocated across, and parallel to, natural and anthropogenic barriers (Bélisle and St Clair 2001; Laurance and Gomez 2005). Most species took longer to return when translocated across canopy gaps but differences among species were evident (Bélisle and St Clair 2001). Adult resident animals were translocated because they would be more highly motivated to return to their previous home range. Techniques such as baits and playback vocalisations that have been used to attract other taxa across linear barriers (Burnett 1992; Goosem and Marsh 1997; St Clair 2003) were not suitable for the lemuroid ringtail, a specialist folivore that rarely vocalises (Goudberg 1990).

\section{Materials and methods}

\section{Study sites}

Two study sites were established in upland rainforest on the Atherton Tablelands in the Wet Tropics of the Queensland World Heritage Area, Australia. The rainforest at both sites was logged before World Heritage Listing in 1988 and is still internally fragmented by forestry tracks, which usually return some canopy closure. Sites were chosen for ease of access, had low traffic volume (1-2 vehicles day $\left.{ }^{-1}\right)$ and previous surveys indicated the presence of reasonable numbers of $H$. lemuroides. Site 1, at Mt Father Clancy (Forest Type 1a 'Complex Mesophyll Vine Forest' (Tracey 1982), $17^{\circ} 35^{\prime} \mathrm{S}, 145^{\circ} 38^{\prime} \mathrm{E}$, altitude $780 \mathrm{~m}$ ) consisted of $3 \mathrm{~km}$ of forestry road of compacted dirt, $3 \mathrm{~m}$ wide with $2 \mathrm{~m}$ bare/short grass shoulders with extended canopy gaps (200 $\mathrm{m}$ long $\times 5-20 \mathrm{~m}$ wide). This transect was used to examine home-range size around roads and for the road-translocation experiment. The distance between forest edges at ground level measured in September 1997 at $25-\mathrm{m}$ intervals was $15.50 \pm$ $4.3 \mathrm{~m}$ (mean \pm s.e., $n=120$ ) and the canopy gap size over the road was $7.78 \pm 4.34 \mathrm{~m}$ (mean \pm s.e.); there were five locations where the canopy joined and 45 locations where the gap size was $<5 \mathrm{~m}$. Site 2, at Longlands Gap (Forest Type 5a 'Complex
Notophyll Vine Forest' (Tracey 1982), $17^{\circ} 23^{\prime} \mathrm{S}, 145^{\circ} 23^{\prime} \mathrm{E}$, altitude $1100 \mathrm{~m}$ ), was $20 \mathrm{~km}$ from Mt Father Clancy. It comprised an 80-m-wide powerline corridor bisecting closed forest and was used for the powerline-translocation experiment. The powerline corridor was vegetated with guinea grass (Panicum maximum), blady grass (Imperata cylindrica), lantana (Lantana camara) and other small shrubs during this study.

\section{Capture and radio-telemetry}

To locate animals for capture and radio-collaring, spotlighting transects were conducted between 1800 and 2400 hours four times a week between December 1995 and August 1997 at Mt Father Clancy and between January and August 1998 at Longlands Gap. Spotlights $(30 \mathrm{~W})$ covered with a neutraldensity filter to reduce light intensity to $7 \mathrm{~W}$ were used to locate animals.

Thirty-five animals were caught across both sites but only 32 were collared; juveniles were not collared. Twenty-nine were caught using tranquilliser darts filled with Zoletil fired from a gas-powered Monotech Model 2 gun equipped with a laser night-sight (Monotech Pty Ltd, Melbourne). Lemuroids that were not darted were shaken out of small trees and caught in a sheet. At Mt Father Clancy, 24 H. lemuroides were captured and radio-collared; ten were released at point of capture, seven translocated within the forest and seven across the road. Eight animals were collared and translocated across the powerline corridor at Longlands Gap. All animals were sexed, weighed and measured, and fitted with two-stage transmitters (Sirtrack, Havelock North, NZ) and a passive integrated transponder. Each transmitter weighed $18 \mathrm{~g}, 2 \%$ of the average weight of the possums. The transmitters were initially mounted on strips of leather and fitted snugly around the neck of the possums. The leather was replaced by polyvinyl chloride for collars used on possums radio-tracked across the powerline corridor as the leather hardened and rubbed on the possum's necks. We had problems with the PVC-mounted collars: two of the eight H. lemuroides ripped and dropped their collars within the first month.

Radio-collared possums were located once a night between 1900 and 0530 hours, $2-4$ times a week. The distance along the track at an accuracy of $0.5 \mathrm{~m}$ (tracks were marked at $25-\mathrm{m}$ intervals with reflective tape), and the horizontal distance into the forest perpendicular to the road and to the side of the road on which the animal was located were recorded for each radio-fix. The accuracy of fixes was determined experimentally using control transmitters. These tests and sightings of radio-collared animals indicated that radio-tracking was $100 \%$ accurate in determining the side of the road on which the target animal was located. A combination of weather, local geology, topography and floristics resulted in some radio-signals being diffuse; results from tracking in such conditions were excluded from the analyses of home range.

The vegetation in the powerline corridor at Longlands Gap, which sloped away from the road, was scanned for possums three times a night during 131 visits. Additionally, we scanned for possums within the powerline corridor by walking $200 \mathrm{~m}$ along the edge of the rainforest for one hour once a week over 36 weeks. 


\section{Data analysis}

Home ranges were analysed using the program 'Tracker version 1.1' (Camponotus AB Sweden 1994). We considered that minimum convex polygon (MCP) and $95 \%$ convex polygon $(95 \% \mathrm{CP})$ gave more realistic estimates of home range than the harmonic mean and kernel methods because the latter methods include areas across the barrier where possums were not recorded. We present home-range estimates using all three methods to allow for comparison with other studies, but used MCP and 95\% CP when comparing home ranges and determining road frontages. An estimate of long-distance movements was determined by measuring the distance between the $95 \% \mathrm{CP}$ and $\mathrm{MCP}$, as core area estimates ranged between 70 and $95 \%$ of home-range area. The number of radio-fixes required to estimate the home range of individual $H$. lemuroides, determined from cumulative area curves of incremental sets of radio-tracking data for each animal, varied among individuals (mean \pm s.e. $=48.75$ \pm 3.5 , range $30-60, n=8$ ). Sufficient data to determine a stabilised home range for animals released at their point of capture were obtained for five females and three males (Table 1).

\section{Results}

\section{Home range and movement patterns of possums released at their point of capture}

Home ranges were small (MCP, range $0.15-1.18$ ha; $95 \%$ CP, range $0.13-1.14$ ha; $95 \% \mathrm{CP}$, female mean \pm s.d.: $0.474 \pm$ 0.419 ha, $n=5 ; 95 \%$ CP, male mean \pm s.d.: $0.433 \pm 0.155$ ha, $n=3)$ and significantly different among individuals $(F=5.614$, d.f. $=7,16, P=0.003)$. The smallest and largest home-range estimates were associated with female $H$. lemuroides (Table 1). Natural movements outside the $95 \%$ CP were generally $<25 \mathrm{~m}$ $(n=7)$ (Table 2).

The mean maximum distance between radio-fixes of $H$. lemuroides in each month of the year indicated that the possums moved distances greater than the width of the road in all months (Fig. 1). Movements much greater than the width of the powerline corridor within the forest were uncommon and were mainly conducted at the beginning of the wet season (Fig. 1). A female possum was recorded $103 \mathrm{~m}$ outside her $95 \%$ $\mathrm{CP}$ home-range area on two consecutive nights in December. Fewer animals were radio-tracked in the dry season (June-November) as the animals were not available for capture in that season, but the results suggest that long-distance movements during this season are uncommon. The maximum distance between radio-fixes for any possum in the dry season was $110 \mathrm{~m}$ (dry season mean $=60 \mathrm{~m})$ compared with $239 \mathrm{~m}$ in the wet season (wet season mean $=83 \mathrm{~m}$ ) (Fig. 1).

The length of road associated with each home range varied between 75 and $174 \mathrm{~m}$ (mean \pm s.e.: $105.7 \pm 11.5 \mathrm{~m}, n=9$, based on $95 \% \mathrm{CP}$ ) (Table 2). The inclusion of movements outside the $95 \% \mathrm{CP}$ increased the road frontage to $150.8 \pm 18 \mathrm{~m}$ (mean \pm s.e., range 95-240 m, $n=9$ ) (Table 2). In all cases, the road frontage was much greater than the width of the road and equal to or greater than the width of a powerline corridor (Table 2). The longest axis of the home range of eight of nine resident $H$. lemuroides was along the road, suggesting that the road was influencing their movements.

\section{Use of both sides of the road}

Five of the nine resident $H$. lemuroides were recorded on one side of the road only (Table 2); the remaining four had home ranges that straddled a road. Two females distributed their time equally between both sides of the road (Table 2); they were the only collared $H$. lemuroides with access to canopy linkages over the road in the centre of their home ranges. The other two $H$. lemuroides that used both sides of the road, a female and a male, favoured one side of the road, with $>80 \%$ of radio-fixes on one side. The female had a canopy linkage over the road at the edge of her home range but the male had none (Table 2).

This pattern of use was also found in the data from the translocation experiment where animals had settled into a home range following translocation. That is, the use of both sides of the road was associated with at least one linkage over the road within the territory (likelihood ratio 22.52, d.f. $=4, P=0.0002$ ) (Fig. 2). Possums with a linkage in the central part of their range tended

Table 1. Home-range area of $\boldsymbol{H}$. lemuroides released at their point of capture

Areas were estimated using minimum convex polygon, MCP; convex polygon, CP (95\%); harmonic mean, HM (95\%) and kernel, KM (95\%) methods on total number of fixes. Animal code: $\mathrm{F}=$ female, $\mathrm{M}=$ male. Fixes to stabilise refer to the number of fixes required to obtain a stable home-range estimate

\begin{tabular}{|c|c|c|c|c|c|c|c|c|c|}
\hline $\begin{array}{l}\text { Animal } \\
\text { Code }\end{array}$ & $\begin{array}{c}\text { Season } \\
\text { tracked } \\
\text { (Wet/Dry) }\end{array}$ & $\begin{array}{l}\text { Months } \\
\text { tracked }\end{array}$ & $\begin{array}{l}\text { Total } \\
\text { fixes }\end{array}$ & $\begin{array}{l}\text { Nights } \\
\text { tracked }\end{array}$ & $\begin{array}{c}\text { Fixes to } \\
\text { stabilise } \\
\text { home range }\end{array}$ & $\begin{array}{l}\text { MCP } \\
\text { (ha) }\end{array}$ & $\begin{array}{c}95 \% \text { CP } \\
\text { (ha) }\end{array}$ & $\begin{array}{c}95 \% \text { HM } \\
\text { (ha) }\end{array}$ & $\begin{array}{c}95 \% \mathrm{KM} \\
\text { (ha) }\end{array}$ \\
\hline $\mathrm{F} 1$ & Dry & 3.5 & 32 & 30 & - & - & - & - & - \\
\hline F2 & Wet/Dry & 7 & 74 & 50 & 60 & 0.15 & 0.13 & 0.35 & 0.3 \\
\hline F3 & Wet/Dry & 6 & 67 & 43 & 55 & 0.16 & 0.14 & 0.26 & 0.25 \\
\hline F4 & Wet & 6 & 66 & 63 & 55 & 0.74 & 0.6 & 0.9 & 1 \\
\hline F5 & Wet & 6 & 76 & 70 & 40 & 0.81 & 0.36 & 0.59 & 0.56 \\
\hline F6 & Wet & 6 & 63 & 61 & 45 & 1.18 & 1.14 & 1.96 & 4.07 \\
\hline M1 & Dry/Wet & 7 & 70 & 70 & 50 & 0.52 & 0.37 & 0.75 & 0.64 \\
\hline M2 & Wet & 3.5 & 47 & 41 & 30 & 0.68 & 0.32 & 1.06 & 1.21 \\
\hline M3 & Dry/Wet & 6 & 77 & 74 & 55 & 0.61 & 0.61 & 0.91 & 1 \\
\hline M4 & Wet & 1.5 & 24 & 10 & - & - & - & - & - \\
\hline Mean & & 5.25 & 59.60 & 51.20 & 48.75 & 0.61 & 0.46 & 0.85 & 1.13 \\
\hline s.e. & & 0.57 & 5.95 & 6.48 & 3.50 & 0.12 & 0.12 & 0.19 & 0.44 \\
\hline$n$ & & 10 & 10 & 10 & 8 & 8 & 8 & 8 & 8 \\
\hline
\end{tabular}


Table 2. Home-range characteristics in relation to a 7-m-wide road for nine $H$. lemuroides released at their point of capture Animal code: $\mathrm{F}=$ female; $\mathrm{M}=$ male. Road frontage $95 \% \mathrm{CP}$ : based on $95 \%$ convex polygon home-range estimate; $\mathrm{MCP}=$ minimum convex polygon

\begin{tabular}{|c|c|c|c|c|c|c|c|}
\hline $\begin{array}{l}\text { Animal } \\
\text { Code }\end{array}$ & $\begin{array}{c}\text { Aligned along } \\
\text { road }\end{array}$ & $\begin{array}{l}\text { Range straddled } \\
\text { road }\end{array}$ & $\begin{array}{l}\text { Percentage of } \\
\text { fixes on most- } \\
\text { used side of road }\end{array}$ & $\begin{array}{l}\text { Road frontage } \\
(95 \% \mathrm{CP})(\mathrm{m})\end{array}$ & $\begin{array}{l}\text { Road frontage } \\
(\mathrm{MCP})(\mathrm{m})\end{array}$ & $\begin{array}{l}\text { Canopy linkages } \\
\text { across road }\end{array}$ & $\begin{array}{l}\text { Location of } \\
\text { linkages within } \\
\text { home range }\end{array}$ \\
\hline $\mathrm{F} 1$ & Yes & No & 100 & 150 & 160 & Yes & Edge \\
\hline F3 & Yes & No & 100 & 75 & 95 & No & - \\
\hline F4 & Yes & Yes & 88 & 109 & 142 & Yes & Edge \\
\hline F5 & Yes & Yes & 62 & 91 & 240 & Yes & Centre \& edge \\
\hline M2 & Yes & No & 100 & 100 & 216 & Yes & Edge \\
\hline M3 & No & Yes & 82 & 97 & 116 & No & - \\
\hline
\end{tabular}

to spend equal time on both sides of the road. In contrast, those with no linkages along the length of the road bordering their home range restricted their activities to one side of the road. The exception was one $H$. lemuroides that spent some time on both sides of the road but had no linkage within its estimated home range. It is not known whether this animal was ranging further than indicated by radio-tracking or crossing at ground level.

\section{Translocations}

The translocation distances (mean \pm s.e.: $358 \pm 67 \mathrm{~m}$ ) were twice the road frontage of resident $H$. lemuroides. The proportion of animals that returned to their capture site depended on the site to which they were relocated $\left(\chi^{2}=5.38\right.$, d.f. $=2$, $P=0.07)$. Five ( 2 males and 3 females) of seven ( 4 males and 3 females) animals translocated within contiguous forest returned to the point of capture, three ( 2 males and 1 female) of seven ( 3 males and 4 females) translocated across a road returned and one (male) of eight ( 5 males and 3 females) translocated across a powerline corridor returned. It is not known how these animals returned to their capture site. Those moving across the road may have crossed by one of five canopy linkages, by bridging gaps they could leap or crossing at ground level, but those translocated across the powerline corridor had to come to ground to cross. The time for possums to return to their point of capture ranged between one and eight nights.

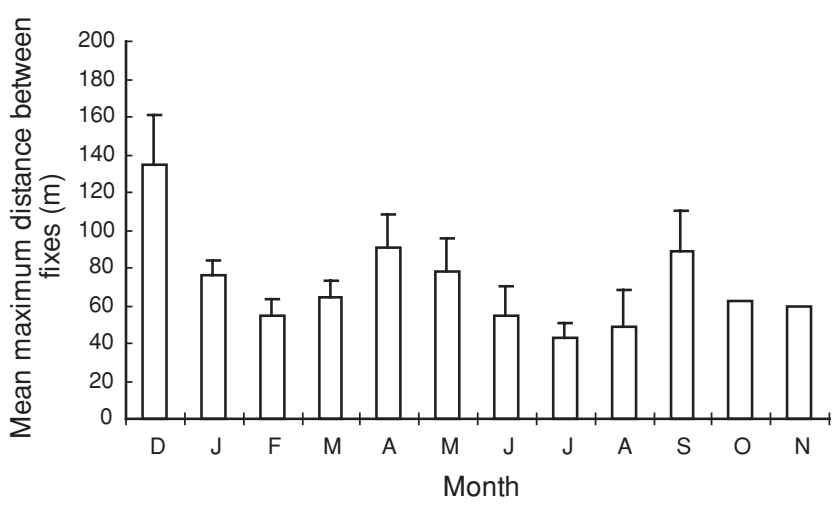

Fig. 1. Maximum distance (mean \pm s.e.) between radio-fixes for each month for $H$. lemuroides released at their point of capture.
Translocated H. lemuroides $(n=22)$ moved greater distances than those $(n=9)$ released at their point of capture $(t=-3.04$, d.f. $=29, P=0.005)$, but this was mainly due to those translocated along and across the road; those translocated across the powerline corridor moved similar distances to those released at their capture point (Fig. 3). The greatest measured distance moved was $568 \mathrm{~m}$ by a female $H$. lemuroides translocated across a road. She did not return to her capture location and moved further into the forest and settled away from the road. Relocated $H$. lemuroides that returned to their capture sites travelled significantly greater distances than those that did not return. This result was independent of whether they were translocated along a road, across a road, or across the powerline corridor (Fig. 4; Table 3).

Of the $H$. lemuroides released at their capture point, only one was recaptured. This possum, a male, had a canopy linkage over the road within its original home range ( $0.68 \mathrm{ha}$ ) and crossed the road at least eight times in the 3.5 months it was radio-tracked before translocation. After translocation along the road, it did not return to its original home range and was recorded on one side of the road only in an area of $\sim 0.32$ ha $(95 \%$ CP, 32 fixes taken over three months).

Most $H$. lemuroides (13 of 14) relocated along and across a road settled near the road. Once settled, the road frontage of

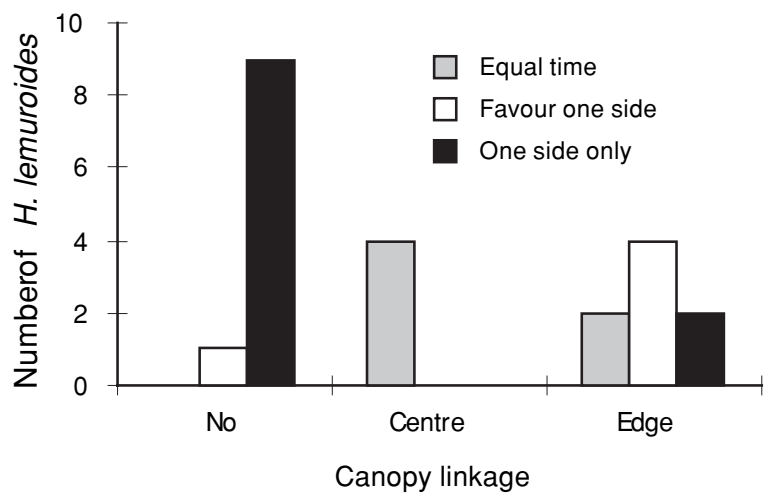

Fig. 2. Use of forest on either side of the road where there was: (1) no linkage, (2) a central linkage, or (3) a linkage at the edge of the home range over the road. 


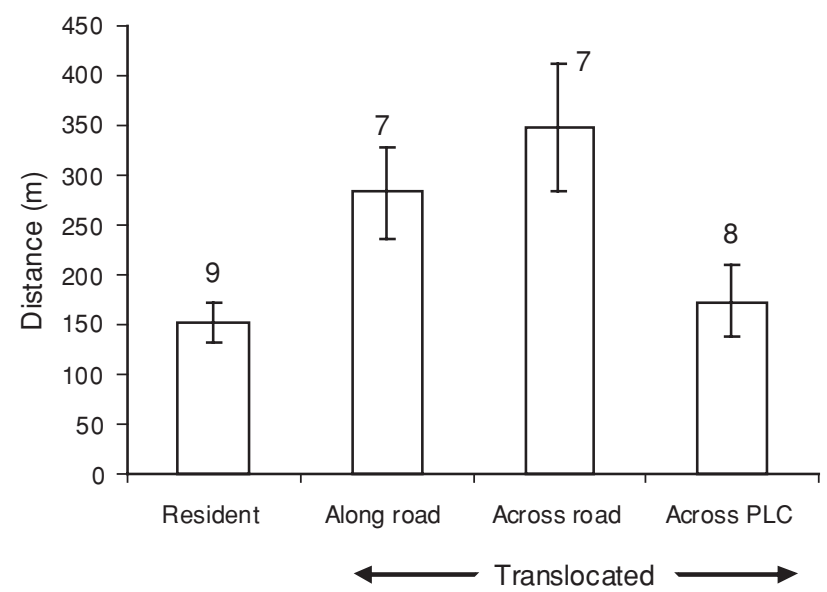

Fig. 3. Length of longest axis (mean \pm s.e.) of home ranges of resident H. lemuroides compared with distance moved (mean \pm s.e.) by translocated $H$. lemuroides from point of release. Resident $=$ possums released at their capture point; PLC $=$ powerline corridor. Numbers above bars refer to number of possums used in the measurements.

territories of possums that returned to their capture point was between 60 and $152 \mathrm{~m}$, while that of those animals that did not return to their capture point was between 37 and $115 \mathrm{~m}$. This group of possums were radio-tracked for an average of $5.31 \pm$ 0.35 (s.e.) months (range 3-7 months).

\section{Translocation across powerline corridor}

Three $H$. lemuroides translocated across the powerline corridor were found dead 4, 13 and 15 days after translocation. A female and a male died of unknown causes, but both were lighter on capture (female $17 \%<$ mean of $1024 \mathrm{~g}, n=15$; male $16 \%<$ mean of $919 \mathrm{~g}, n=14$ ) than other adult H. lemuroides (Wilson 2000). A second female was found freshly killed on the forest floor late in the afternoon 13 days after translocation. Pied currawongs (Strepera graculina) were making a raucous noise in the area where she was discovered and were the probable predators. Animals that were translocated across the powerline corridor were radio-tracked between four days and 2.5 months.

Our experience suggests that possums that had not returned to their capture location within nine nights were most likely to settle elsewhere. Seven of the H. lemuroides translocated across the powerline corridor were radio-tracked for more than nine nights; only one crossed the powerline corridor. This animal returned to his original home range and was sighted emerging

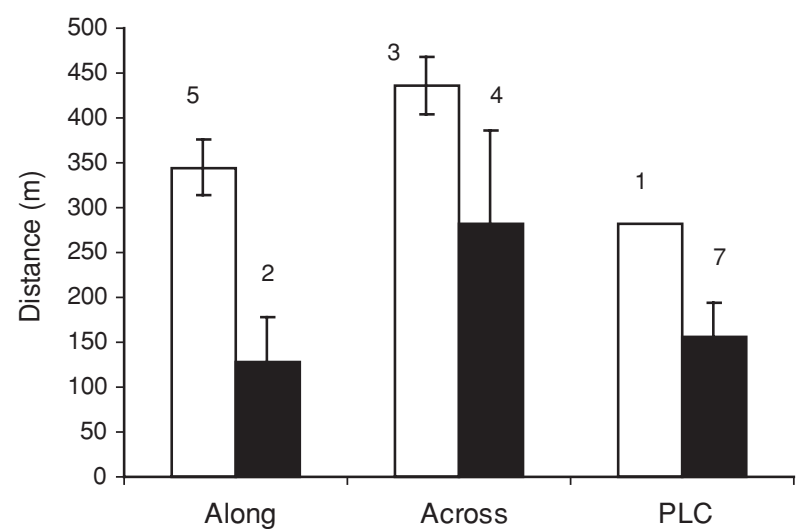

Fig. 4. Distance moved (mean \pm s.e.) by translocated $H$. lemuroides that returned (open bars) and did not return (solid bars ) to their capture point from point of release. PLC $=$ powerline corridor. Numbers above bars refer to number of animals.

from a den in the company of an adult and subadult at the capture location the night after his translocation. He was radiotracked for a further 2.5 months and remained within the forest $140 \pm 2.5 \mathrm{~m}$ from the powerline corridor in an area of 0.70 ha (MCP). This possum was not detected crossing the corridor on his own accord, suggesting that his homing after translocation was not part of his regular movements.

The minimum distance moved from the release point by possums translocated across the powerline corridor ranged between $30 \mathrm{~m}$ and $320 \mathrm{~m}$. The smallest movements of 30 and $76 \mathrm{~m}$ respectively were less than the width of the powerline corridor and were made by the two females that died one and two weeks after translocation. Although the period of radio-tracking this group of possums was short, all of the H. lemuroides radiotracked for more than three weeks $(n=5)$ moved away from the powerline corridor; none established home ranges overlapping or aligned with it, suggesting an avoidance of the canopy break caused by the powerline corridor.

\section{Use of the powerline corridor}

No possums were sighted within the powerline corridor during $16 \mathrm{~h}$ of spotlighting along the edge of the corridor. Additionally, none was sighted during 450 spotlighting scans of $\sim 2$ min each made while crossing the corridor to access both sides of the forest. The mean ( \pm s.e.) number of crossings made by researchers per night was $3.65 \pm 0.41$ (131 nights).

Table 3. Analysis of variance to test whether the recorded distance that $H$. lemuroides moved from its release point following translocation differed between animals that returned to their capture point from those that failed to return Bold indicates a significant value

\begin{tabular}{lcrrrr}
\hline Source of variation & d.f. & s.s. & m.s. & $F$ & $P$ \\
\hline Return/not return $^{\mathrm{A}}$ & 1 & 101557.89 & 101557.89 & 7.49 & $\mathbf{0 . 0 1 5}$ \\
Translocation type $^{\mathrm{AB}}$ & 2 & 65424.33 & 32712.17 & 2.41 & 0.122 \\
Return/not return by translocation type & 2 & 5054.42 & 2527.21 & 0.19 & 0.832 \\
\hline
\end{tabular}

AFixed factor.

${ }^{\mathrm{B}}$ Translocation (along a road; across a road; across a powerline corridor). 


\section{Discussion}

This study demonstrates that partial canopy closure over narrow roads restricts daily movements of the lemuroid ringtail possum, but is unlikely to prevent dispersal or gene flow in populations. As $H$. lemuroides is strictly arboreal and found higher in the canopy than other sympatric folivorous ringtails of similar mass, it is reasonable to conclude that narrow roads with partial canopy closure do not restrict gene flow and dispersal important in the demography of most mammals (Lidicker 1975; Clout and Efford 1984).

Forman and Alexander (1998) reported that roads 6-15 m wide, similar to that in this study, caused a 10 -fold decrease in the probability of small mammals moving between habitat patches. Most of the hypotheses proposed to explain the reduced crossing rates by wildlife have been attributed to traffic noise, lights, fumes and vibration (reviewed in Forman and Alexander 1998). In our study, and that of Goosem (2000), traffic volume was minimal, so traffic disturbance was not considered a factor in animals crossing these roads. Instead, we believe that fragmentation resulting from clearing of canopy linkages over the road results in reduced crossing rates by $H$. lemuroides and is likely to have the same effect on other arboreal mammals (Pahl et al. 1988; Laurance 1990). This is supported by Pahl et al. (1988) and Laurance (1990), who found no evidence that lemuroids used regrowth or other non-rainforest habitats.

Proportionally equal numbers of adult male and female lemuroid ringtails homed after translocation and males were more likely to cross canopy gaps than females. This trend may be associated with different dispersal behaviour between sexes and thus a difference in knowledge of an area. For example, juvenile male brushtail possums (Trichosurus vulpecula) disperse more than females (Clout and Efford 1984) and male red squirrels (Tamiasciurus hudsonicus) have higher homing success than females, presumably because they have a larger familiar area (Bakker and Van Vuren 2004).

When canopy linkages were present, the home range of lemuroid ringtails straddled the road. However, where no linkage was available their home range was restricted to one side of the road and aligned with it. This supports our hypothesis that canopy connectivity over roads is important to the movements of this species. Goudberg (1990) reported that arboreal possums use 'canopy highways' to negotiate the forest. Our observations and those of Weston (2003) of possums using canopy linkages across roads are consistent with this result and indicate the importance of maintaining such linkages or providing artificial linkages over clearings. For many understorey Amazonian birds even clearings 30-40 m wide greatly reduce their movements and for some species clearings of $>200 \mathrm{~m}$ halt them altogether (Laurance 2004).

In contrast to studies of terrestrial mammals (mule deer (Odocoileus hemionus) and elk (Cervus canadensis): Rost and Bailey 1979; grizzly bear (Urus horribilis): McLellan and Shackleton 1988; and black bear (Euarctos americanus): Brody and Pelton 1989) and understorey rainforest birds (Laurance et al. 2004), H. lemuroides did not apparently avoid the 'hard' edge of the road. Large terrestrial animals allegedly avoid road edges because of traffic disturbance, factors not affecting the roads in this study or that of Goosem (2000). However, Goosem
(2000) found that rainforest rodents also avoided the road edge, perhaps because of the proliferation of weeds. Roadside clearing along narrow roads tends to affect ground strata and not the subcanopy and canopy where the possums occur.

$H$. lemuroides living adjacent to roads aligned their home range with the road. Small mammals also align home ranges with linear features as a result of social spacing (Mader 1984; Stamps et al. 1987). Burnett (1992) suggests that social spacing may be a causative mechanism for linear barrier effects along habitat discontinuities, an explanation that is plausible here. This alignment of home ranges with roads may impose artificial home-range boundaries that restrict reproductive opportunities of animals that cross them (see Riley et al. 2006).

Although $H$. lemuroides is clearly capable of moving distances greater than the width of a powerline corridor, it appears reluctant to do so, suggesting that some psychological factor such as avoidance of open spaces affects its behaviour. Pires and Fernandez (1999) found a similar response by the forest-dependent long-furred woolly mouse opossum ( $M$. demerarae) in South America. Another forest-dependent small mammal, the red squirrel, also favours detours within forest over a more direct route across a clearing (Bakker and Van Vuren 2004). This is important as the reluctance to cross will disrupt social interactions, dispersal and gene flow that for small isolated populations could result in extinction (Laurance 1997). Small populations can be 'rescued' by both the demographic and genetic contributions of immigrants, thus providing a buffer against local extinction (Brown and Kodric-Brown 1977). However, for migration to be genetically effective high levels of migration may be needed (Riley et al. 2006).

Clearly, H. lemuroides translocated across the powerline corridor were unwilling or unable to cross it. This contrasts with the behaviour of forest-dependent red squirrels translocated across comparable canopy gaps, 14 of 36 of which crossed the canopy gaps (Bakker and Van Vuren 2004). Interestingly, those that crossed were mostly females of lower mass in the capture group, whereas males homed by taking detours through the forest. Although the behaviour of these two forest mammals to loss of canopy connectivity is different, it is possible that similar decisions about crossing a gap are affecting their movements. Such decisions include perceived predation risk, energetic costs, probability of encounters with conspecifics, and ease of regaining territory and mate following an absence (Bakker and Van Vuren 2004).

\section{Mitigation options}

Homing by most lemuroid ringtails translocated within forest indicates they are highly motivated to return to their established territory and/or mate. Therefore, the significant inhibition of movements across a clearing of $80 \mathrm{~m}$, combined with evidence from other species that even moderate levels of migration contribute little to gene flow (Riley et al. 2006), suggests that lemuroid ringtails may become, or are already, isolated within fragmented forest. This makes small populations of this species vulnerable to extinction (Laurance 1990).

The location of a canopy linkage over roads in the home range of $H$. lemuroides influenced their use of habitat on both sides of it, highlighting the need to maintain regular linkages along linear barriers within their habitat. Weston (2003) has 
shown that several species of non-volant arboreal mammals, including the lemuroid possum, will cross narrow roads via rope bridges. Will these species cross wider canopy gaps using such structures? Because metapopulation models indicate that fragmentation of habitat severely reduces the chance of survival of a species (Poethke et al. 1996), it is important that canopy linkages are provided within the core habitat to ensure movements of these species. To maintain social integration and genetic diversity across a linear barrier for these possums, a linkage every $100 \mathrm{~m}$ is required (on the basisof road frontages of the lemuroids); this would provide one linkage for every home range. The reason for maintaining genetic diversity in local populations is that it provides the population with a greater chance of adapting to a changing environment and a reduced area of suitable habitat, with the increasing likelihood of significant global climate change (Mortiz et al. 1997). A warming of $1{ }^{\circ} \mathrm{C}$ in the humid tropics of north Queensland is predicted to occur within 50 years and modelling shows that this will result in a $50 \%$ decrease in upland rainforest, even if rainfall remains constant (Hilbert et al. 2001; Williams et al. 2003).

Narrow roads are clearly a partial barrier to everyday movements of the lemuroid possum but are unlikely to restrict its gene flow, whereas powerline corridors are a major obstacle and likely to disrupt the metapopulation dynamics of this species. We recommend that future studies should focus on (1) identifying roads in critical habitat, which is in complex mesophyll rainforest on basalt soils, of arboreal mammals that need the restoration of canopy linkages, (2) developing techniques to assist arboreal movements over wide busy roads, and (3) genetic profiling of individuals and an examination of the genetic variation between rainforest ringtail possums located either side of a wide habitat discontinuity to determine whether these corridors are isolating populations of arboreal mammals.

\section{Acknowledgements}

This study was supported by a Ph.D. scholarship from the Cooperative Research Centre for Rainforest Ecology and Management and a research grant from James Cook University to Robyn Wilson. CSIRO, Atherton, provided space and facilities for data analysis and write-up. Valuable field assistance was provided by Gary Wilson and Leslie Brown. Animal Ethics approval was obtained for this study from the James Cook University Animal Ethics Committee. We also thank two anonymous reviewers whose comments and suggestions were very much appreciated.

\section{References}

Andrews, A. (1990). Fragmentation of habitat by roads and utility corridors: a review. Australian Zoologist 26, 130-141.

Bakker, V. J., and Van Vuren, D. H. (2004). Gap-crossing decisions by the red quirrel, a forest-dependent small mammal. Conservation Biology 18, 689-697. doi:10.1111/j.1523-1739.2004.00149.x

Bélisle, M., and St Clair, C. C. (2001). Cumulative effects of barriers on the movements of forest birds. Conservation Ecology 5(2): 9. [online] URL: $\mathrm{http} / / \mathrm{www}$. consecol.org/vol5/iss2/art9/

Bennett, A. F. (1991). Roads, roadsides and wildlife conservation: a review. In 'Nature Conservation 2: The Role of Corridors'. (Eds D. A. Saunders and R. J. Hobbs.) pp. 99-118. (Surrey Beatty: Sydney.)

Brody, A. J., and Pelton, M. R. (1989). Effects of roads on black bear movements in western North Carolina. Wildlife Society Bulletin 17, 5-10.

Brown, J. H., and Kodric-Brown, A. (1977). Turnover rates in insular biogeography: effect of immigration on extinction. Ecology 58, 445-449. doi: $10.2307 / 1935620$
Burnett, S. E. (1992). Effects of a rainforest road on movements of small mammals: mechanisms and implications. Wildlife Research 19, 95-104. doi:10.1071/WR9920095

Camponotus AB and Radio Locations Systems AB (1994). 'Tracker: wildlife tracking and analysis software user manual. Version 1.1.' (Solna and Huddinge: Sweden.)

Caughley, G., and Sinclair, S. R. E. (1994). 'Wildlife Ecology and Management.' (Blackwell Science: Melbourne.)

Chepko-Sade, B. D., and Haplin, Z. T. (1987). 'Mammalian Dispersal Patterns.' (The University of Chicago Press: Chicago.)

Clout, M. N., and Efford, M. G. (1984). Sex differences in the dispersal and settlement of brushtail possums (Trichosurus vulpecula). Journal of Animal Ecology 53, 737-749. doi:10.2307/4656

Forman, R. T. T., and Alexander, L. E. (1998). Roads and their major ecological effects. Annual Review of Ecology and Systematics 29, 207-231. doi:10.1146/annurev.ecolsys.29.1.207

Gilpin, M. E., and Soulé, M. E. (1986). Minimum viable populations: processes of species extinction. In 'Conservation Biology: the Science of Scarcity and Diversity'. (Ed. M. E. Soulé.) pp. 19-34. (M. E. Sinauer: Sunderland, MA.)

Goosem, M. (1997). Internal fragmentation: the effects of roads, highways, and powerline clearings on movements and mortality of rainforest vertebrates. In 'Tropical Forest Remnants: Ecology, Management, and Conservation of Fragmented Communities'. (Eds W. F. Laurance and R. O. Bierregaard Jr.) pp. 241-255. (University of Chicago Press: Chicago.)

Goosem, M. W. (2000). Effects of tropical rainforest roads on small mammals: edge changes in community composition. Wildlife Research 27, 151-163. doi:10.1071/WR98091

Goosem, M. W., and Marsh, H. (1997). Fragmentation of a small mammal community by a powerline corridor through tropical rainforest. Wildlife Research 24, 613-629. doi:10.1071/WR96063

Goudberg, N. (1990). The feeding ecology of three species of north Queensland rainforest possums, Hemibelideus lemuroides, Pseudocheirus herbertensis and Pseudocheirus archeri (Marsupialia: Petauridae). Ph.D. Thesis, James Cook University, Townsville.

Hilbert, D. W., Ostendorf, B., and Hopkins, M. S. (2001). Sensitivity of tropical forests to climate change in the humid tropics of north Queensland. Austral Ecology 26, 590-603. doi:10.1046/j.1442-9993.2001.01137.x

Laurance, S. G. W. (2004). Responses of understorey rain forest birds to road edges in central Amazonia. Ecological Applications 41, 1344-1357.

Laurance, S. G. W., and Gomez, M. (2005). Clearing width and movement of understorey rainforest birds. Biotropica 37, 149-152.

Laurance, S. G. W., Stouffer, P. C., and Laurance, W. F. (2004). Effects of road clearings on movement patterns of understorey rainforest birds in central Amazonia. Conservation Biology 18, 1099-1109. doi:10.1111/ j.1523-1739.2004.00268.x

Laurance, W. F. (1990). Comparative responses of five arboreal marsupials to tropical forest fragmentation. Journal of Mammalogy 71, 641-653. doi: $10.2307 / 1381805$

Laurance, W. F. (1997). Responses of mammals to rainforest fragmentation in tropical Queensland: a review and synthesis. Wildlife Research 24, 603-612. doi:10.1071/WR96039

Laurance, W. F. (1999). Reflections on the tropical deforestation crisis. Biological Conservation 91, 109-117. doi:10.1016/S0006-3207(99) 00088-9

Laurance, W. F., and Bierregaard, R. O. Jr. (1997). 'Tropical Forest Remnants: Ecology, Management, and Conservation of Fragmented Communities.' (The University of Chicago Press: Chicago.)

Laurance, W. F., and Laurance, S. G. (1996). Reponses of five arboreal marsupials to recent selective logging in tropical Australia. Biotropica 28, 310-322. doi:10.2307/2389195 
Laurance, W. F., Ferreira, L. V., Rankine-de Merona, J. M., and Laurance, S. G. (1998). Rain forest fragmentation and dynamics of Amazonian tree communities. Ecology 79, 2032-2044. doi:10.2307/ 176707

Lidicker, W. Z. (1975). The role of dispersal in the demography of small mammals. In 'Small Mammals: Their Productivity and Population Dynamics'. (Eds F. B. Golley, K. Petrusewicz and L. Ryszkowski.) pp. 103-128. (Cambridge University Press: London.)

Lindenmayer, D. B., and Franklin, J. F. (2002). 'Conserving Forest Biodiversity.' (Island Press: Washington, DC.)

Mader, H. J. (1984). Animal habitat isolation by roads and agricultural fields. Biological Conservation 29, 81-96. doi:10.1016/00063207(84)90015-6

McLellan, B. N., and Shackleton, D. M. (1988). Grizzly bears and resource extraction industries: effects of roads and behaviour, habitat use and demography. Journal of Applied Ecology 25, 451-460. doi:10.2307/ 2403836

Middleton, J. (1993). The intrusive effects of a powerline corridor on the small mammal community of a tropical rainforest. B.Sc.(Honours) Thesis, James Cook University, Cairns.

Mortiz, C., and Joseph, L., Cunningham, M., and Schnieider, C. (1997). Molecular perspectives on historical fragmentation of Australian tropical and subtropical rainforests: implications for conservation. In 'Tropical Forest Remnants: Ecology, Management, and Conservation of Fragmented Communities'. (Eds W. F. Laurance and R. O. Bierregaard Jr.) pp. 442-454. (University of Chicago Press: Chicago.)

Newman, J. A., Recer, G. M., Zwicker, S. M., and Caraco, T. (1988). Effects of predation hazard on foraging 'constraints': patch-use strategies in grey squirrels. Oikos 53, 93-97. doi:10.2307/3565668

Pahl, L. I., Winter, J. W., and Heinsohn, G. (1988). Variation in the responses of arboreal marsupials to fragmentation of tropical rainforest in northeastern Australia. Biological Conservation 46, 71-82. doi:10.1016/ 0006-3207(88)90109-7

Pires, A. S., and Fernandez, F. A. S. (1999). Use of space by the marsupial Micoureus demerarae in small Atlantic forest fragments in south-eastern Brazil. Journal of Tropical Ecology 15, 279-290. doi:10.1017/ S0266467499000814

Poethke, H. J., Seitz, A., and Wissel, C. (1996). Species survival and metapopulations: conservation implications from ecological theory. In 'Species Survival in Fragmented Landscapes'. (Eds J. Settle, C. R. Margules, P. Poschold and K. Henle.) pp. 91-92. (Kluwer Academic Publishers: The Netherlands.)
Riley, S. P. D., Pollinger, J. P., Sauvajot, R. M., Yoir, E. C., Bromley, C., Fuller, T. K., and Wayne, W. (2006). A southern Californa freeway is a physical and social barrier to gene flow in carnivores. Molecular Ecology 15, 1733-1741. doi:10.1111/j.1365-294X.2006.02907.x

Rost, G. R., and Bailey, J. A. (1979). Distribution of mule deer and elk in relation to roads. Journal of Wildlife Management 43, 634-641. doi: $10.2307 / 3808741$

Stamps, J. A., Buechner, M., and Krishan, V. V. (1987). The effects of edge permeability and habitat geometry on emigration from patches of habitat. American Naturalist 129, 533-552. doi:10.1086/284656

St Clair, C. C. (2003). Comparative permeability of roads, rivers, and meadows to songbirds in Banff National Park. Conservation Biology 17, 1151-1160. doi:10.1046/j.1523-1739.2003.02156.x

Tracey, G. (1982). 'The Vegetation of the Humid Tropical Region of North Queensland.' (CSIRO Publishing: Melbourne.)

Werren, G. L. (1993). Conservation strategies for rare and threatened vertebrates of Australia's Wet Tropics Region. Memoirs of the Queensland Museum 34, 229-241.

Weston, N. G. (2003). The provision of canopy bridges to reduce the effects of linear barriers on arboreal mammals in the Wet Tropics of northeastern Queensland. M.Sc. Thesis, James Cook University, Cairns.

Williams, S. E., Bolitho, E. E., and Fox, S. (2003). Climate change in Australian tropical rainforests: an impeding environmental catastrophe. Proceedings Royal Society London, 03PB0103.1-03PB0103.6.

Wilson, R. F. (2000). The impact of anthropogenic disturbance on four species of arboreal folivorous possums in the rainforest of north eastern Queensland, Australia. Ph.D. Thesis, James Cook University, Townsville.

Winter, J. W. (1984). Conservation studies of tropical rainforest possums. In 'Possums and Gliders'. (Eds A. P. Smith and I. D. Hume.) pp. 469-481. (Australian Mammal Society: Sydney.)

Winter, J. W., Bell, F. C., Pahl, L. I., and Atherton, R. G. (1987). Rainforest clear felling in northeastern Australia. Proceedings of the Royal Society of Queensland 98, 41-57.

Young, K. (1994). Roads and the environmental degradation of tropical montane forests. Conservation Biology 8, 972-976. doi:10.1046/j.15231739.1994.08040972.x

Manuscript received 22 August 2006, accepted 1 May 2007 